\title{
Effect of germ cell depletion on levels of specific mRNA transcripts in mouse Sertoli cells and Leydig cells
}

\author{
P J O'Shaughnessy, L Hu and P J Baker \\ Division of Cell Sciences, Institute of Comparative Medicine, University of Glasgow Veterinary School, Bearsden \\ Road, Glasgow G61 1QH, UK \\ Correspondence should be addressed to PJ O’Shaughnessy; Email: p.j.oshaughnessy@vet.gla.ac.uk
}

\begin{abstract}
It has been shown that testicular germ cell development is critically dependent upon somatic cell activity but, conversely, the extent to which germ cells normally regulate somatic cell function is less clear. This study was designed, therefore, to examine the effect of germ cell depletion on Sertoli cell and Leydig cell transcript levels. Mice were treated with busulphan to deplete the germ cell population and levels of mRNA transcripts encoding 26 Sertoli cell-specific proteins and 6 Leydig cell proteins were measured by real-time PCR up to 50 days after treatment. Spermatogonia were lost from the testis between $\mathbf{5}$ and $\mathbf{1 0}$ days after treatment, while spermatocytes were depleted after 10 days and spermatids after 20 days. By 30 days after treatment, most tubules were devoid of germ cells. Circulating FSH and intratesticular testosterone were not significantly affected by treatment. Of the 26 Sertoli cell markers tested, 13 showed no change in transcript levels after busulphan treatment, 2 showed decreased levels, 9 showed increased levels and 2 showed a biphasic response. In $60 \%$ of cases, changes in transcript levels occurred after the loss of the spermatids. Levels of mRNA transcripts encoding Leydig cellspecific products related to steroidogenesis were unaffected by treatment. Results indicate (1) that germ cells play a major and widespread role in the regulation of Sertoli cell activity, (2) most changes in transcript levels are associated with the loss of spermatids and (3) Leydig cell steroidogenesis is largely unaffected by germ cell ablation.
\end{abstract}

Reproduction (2008) 135 839-850

\section{Introduction}

Germ cell proliferation, meiosis and differentiation during spermatogenesis are critically dependent on the actions of follicle-stimulating hormone (FSH) and androgens mediated through the Sertoli cells. Loss of androgens and, to a lesser extent, FSH disrupts spermatogenesis (Lyon \& Hawkes 1970, Kumar et al. 1997, De Gendt et al. 2004), while depletion and loss of function of the Sertoli cells lead to massive degeneration of the haploid germ cells and eventually to almost complete loss of germ cells (Russell et al. 2001). Overall, the Sertoli cells act to maintain spermatogenesis through provision of a structural support, generation of a unique environment in which the germ cells develop, movement of the germ cells as they progress through spermatogenesis and through secretion of factors, which aid germ cell development and differentiation (Mruk \& Cheng 2004). Spermatogenesis is highly organised and orchestrated by the Sertoli cells and appears, in most mammals, as a wave within the tubule. While the role of the Sertoli cell in the process of spermatogenesis is apparent, the extent to which germ cells regulate Sertoli cell activity is less clear. Previous studies have shown that germ cell depletion can alter expression of Sertoli cell genes (Maguire et al. 1993, Jonsson et al. 1999) and secretion of specific Sertoli cell proteins (McKinnell \& Sharpe 1997, Guitton et al. 2000). In addition, co-culture experiments have shown that factors secreted by the germ cells can influence Sertoli cell activity (Boitani et al. 1981, Le Magueresse \& Jégou 1986, Syed et al. 1999, Vidal et al. 2001, Zabludoff et al. 2001, Delfino et al. 2003). Cryptorchidism has also been shown to affect Sertoli cell activity (Johnston et al. 2004, O'Shaughnessy et al. 2007a), although this may be a direct effect of increased temperature on the Sertoli cells (Bergh \& Soder 2007). Overall, there has not been an extensive survey of either the role of germ cells in regulating Sertoli cell gene expression in vivo or the extent to which overall Sertoli cell activity is affected. In this study, therefore, we have treated outbred mice with busulphan and measured changes in the level of 26 different mRNA species expressed specifically in the Sertoli cells as germ cell depletion progresses.

Androgen secretion by the testis is dependent upon the Leydig cells, which are regulated by luteinising hormone 
(LH). There is also good evidence, however, that the Sertoli cells influence Leydig cell activity and that ablation of the Sertoli cell population will lead to loss of the Leydig cells (Russell et al. 2001). We have, therefore, also measured Leydig cell activity and function in germ cell-depleted mice to determine whether the germ cells can directly or indirectly affect the steroidogenic function of the testis.
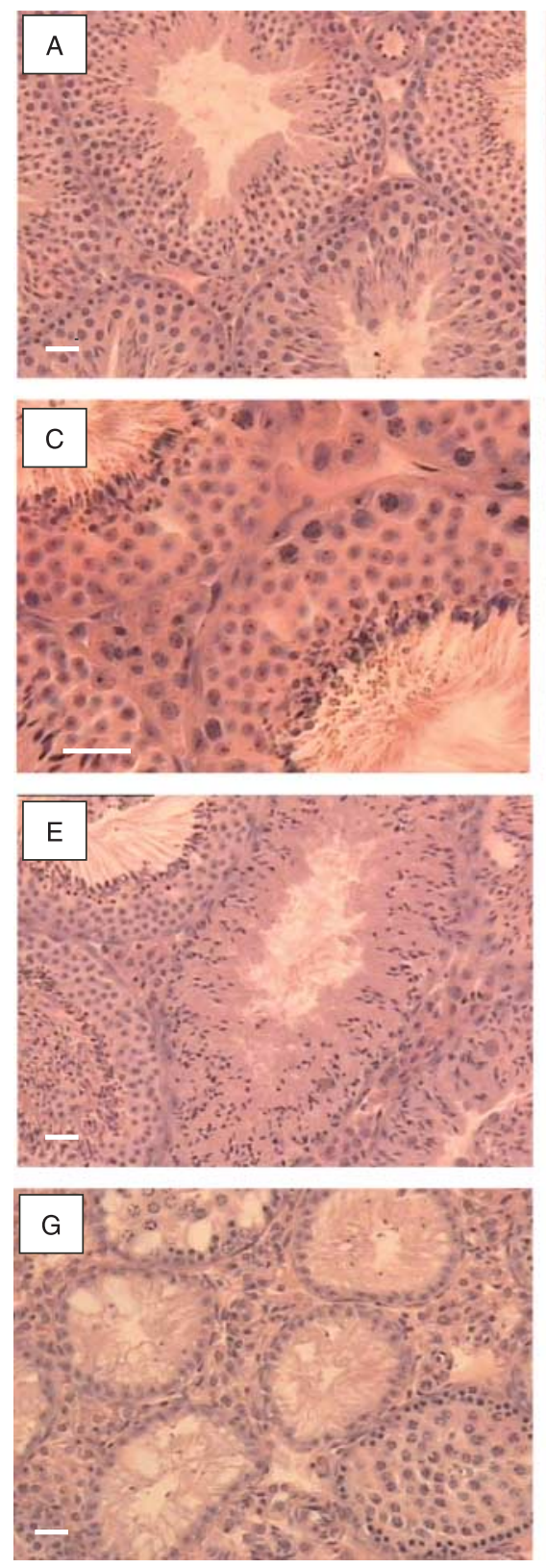

\section{Results}

\section{Testis morphology}

Busulphan treatment had no apparent effect on testis morphology up to day 5 (Fig. 1A and B). By day 10, however, spermatogonia had been depleted and by day 15 the number of spermatocytes had been reduced (Fig. 1C and D). Twenty days after busulphan treatment
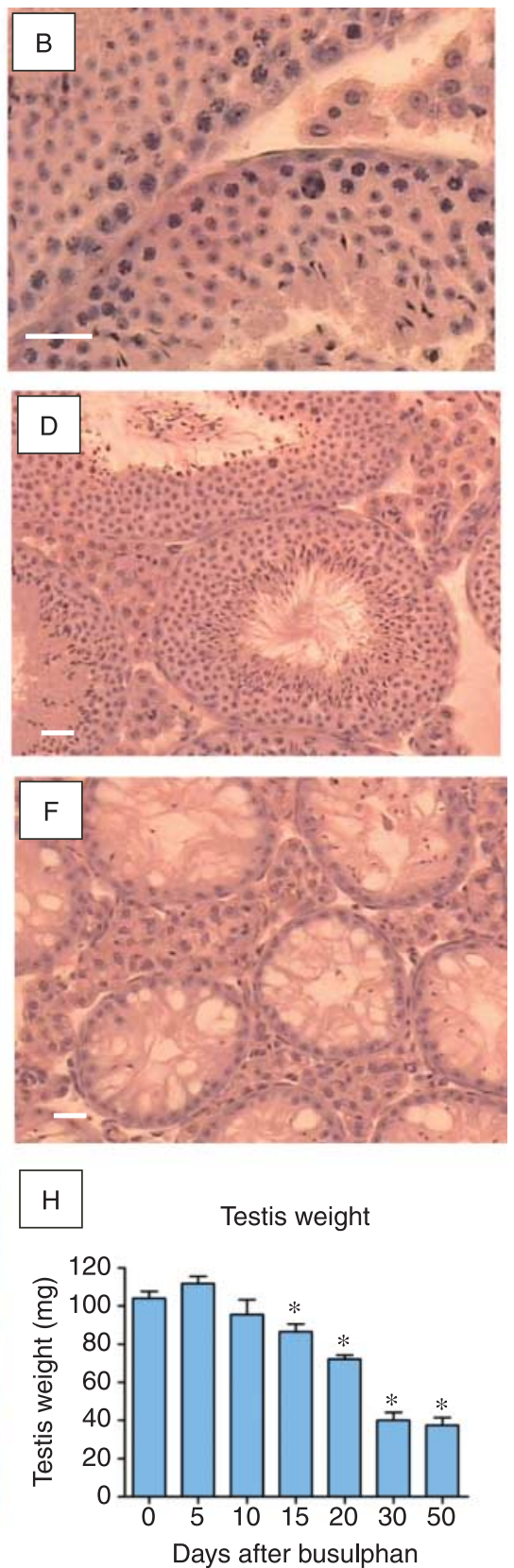

Figure 1 Testicular histology and testis weight following busulphan treatment. Adult mice were given a single injection of busulphan and killed up to 50 days later. Tissue sections show morphology in control (A) testes and (B) 5 days, (C) 10 days, (D) 15 days, (E) 20 days, (F) 30 days and (G) 50 days after busulphan treatment. There was depletion of spermatogonia 10 days after busulphan treatment while spermatocytes were reduced by day 15 and by day 20 some tubules contained only elongated spermatids and spermatozoa. By 30 days tubules were largely devoid of germ cells and by 50 days early regeneration was apparent in some tubules. $(\mathrm{H})$ Testis weight over the course of the experiment. The bar represents $30 \mu \mathrm{m}$. In $(\mathrm{H})$, groups marked with an asterisk $(*)$ are significantly different $(P<0.05)$ from control values. 

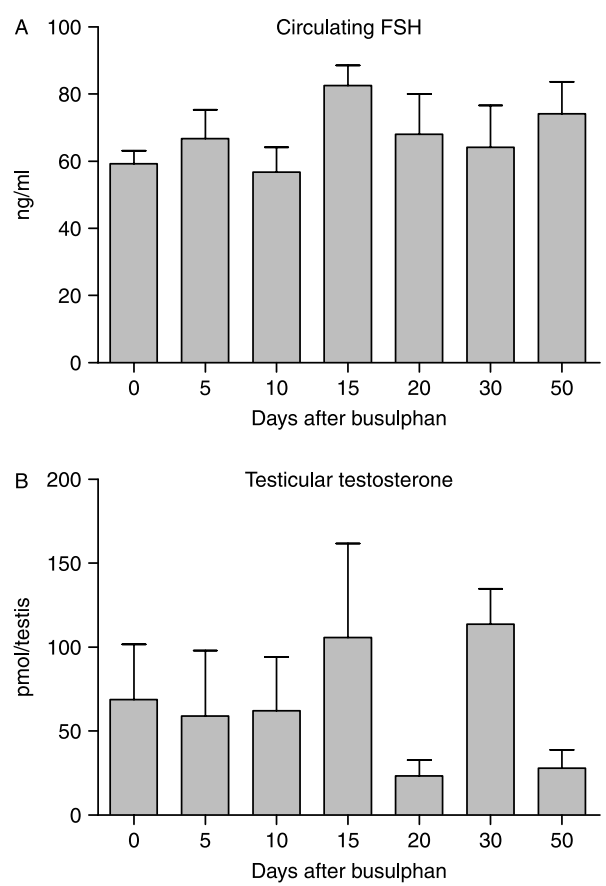

Figure 2 Levels of (A) serum FSH and (B) intratesticular testosterone following busulphan treatment. Serum and tissue were collected at different times after a single injection of busulphan and hormone levels measured as described in Materials and Methods. The results are expressed as mean \pm S.E.M. for four or five animals in each busulphantreated group and 18 animals in the control group. There was no significant $(P<0.05)$ effect of busulphan on levels of either hormone.

some tubules contained only elongated spermatids and spermatozoa, although other tubules still contained round spermatids (Fig. 1E). By 30 days nearly all tubulues were devoid of germ cells, although some spermatozoa were still present in a few tubules (Fig. 1F). Fifty days after treatment most tubules remained devoid of germ cells, although early regeneration was apparent in some tubules (Fig. 1G). Progressive loss of germ cell populations was reflected in declining testis weight (Fig. 1H).

\section{Hormone profiles}

Circulating levels of FSH did not change after busulphan treatment (Fig. 2). There was large variation in intratesticular levels of testosterone between animals but no significant change in response to busulphan treatment (Fig. 2).

\section{Germ cell genes}

Expression levels of three mRNA species encoding markers of different germ cell populations were measured following busulphan treatment to monitor loss of each population. The three markers examined were Stra8, Spo11 and Tnp1, which show predominant expression in spermatogonia, spermatocytes and spermatids
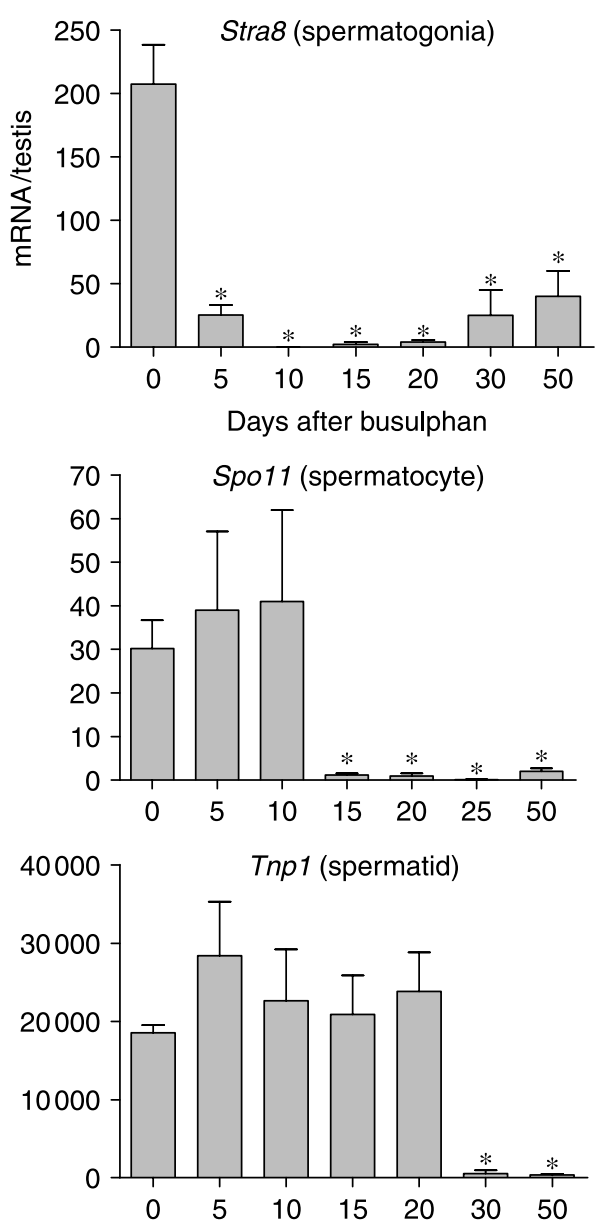

Figure 3 Effect of busulphan treatment on levels of three mRNA transcripts encoding markers of germ cell differentiation. Expression was measured by real-time PCR, and results are expressed relative to the external control luciferase. Data shows expression of the spermatogonial marker Stra8, the spermatocyte marker Spo11 and the spermatid marker Tnp1. The results are expressed as mean \pm s.E.M. for four or five animals in each busulphan-treated group and 18 animals in the control group. Groups marked with an asterisk $(*)$ are significantly $(P<0.05)$ different from control values.

respectively (Yelick et al. 1989, Oulad-Abdelghani et al. 1996, Shannon et al. 1999). Levels of Stra8 mRNA were significantly reduced on day 5 and were barely detectable by day 10 (Fig. 3). The expression recovered slightly by 30 days but remained significantly less than control up to day 50 (Fig. 3). Expression of Spo11 was normal up to day 10 but was significantly and markedly reduced on day 15 with little recovery up to day 50 (Fig. 3). There was no change in Tnp1 expression up to 20 days but between 20 and 30 days there was a marked decline in expression which was maintained up to 50 days.

\section{Leydig cell-specific genes}

To determine whether Leydig cell function is affected by germ cell depletion levels of five Leydig cell-specific mRNA species (Lhr, Star, Hsd3b6, Cyp17a1 and Cyp11a1) were 

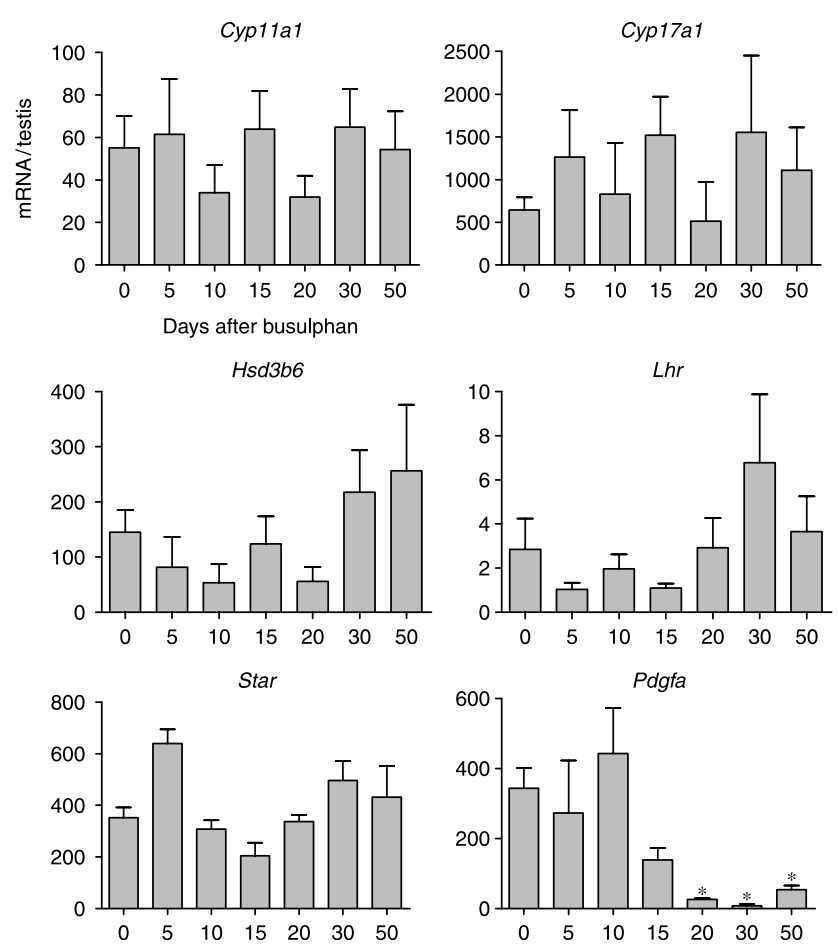

Figure 4 Effect of busulphan treatment on levels of mRNA transcripts encoding Leydig cell-specific products. Expression was measured by real-time PCR, and results are expressed relative to the external control luciferase. The results are expressed as mean \pm s.E.M. for four or five animals in each busulphan-treated group and 18 animals in the control group. Groups marked with an asterisk $\left(^{*}\right)$ are significantly $(P<0.05)$ different from control values.

measured following busulphan treatment. No significant changes in transcript levels encoding the $\mathrm{LH}$ receptor, STAR protein or steroidogenic enzymes were seen following busulphan treatment (Fig. 4). There was, however, a significant decrease in mRNA encoding platelet-derived growth factor (PDGF)-A 20 days after treatment.

\section{Sertoli cell-specific genes}

To examine the effects of germ cell ablation on Sertoli cell activity, the levels of 26 Sertoli cell-specific mRNA species were measured (Fig. 5). There were no changes in the expression levels of 13 mRNAs (Rhox5, Espn, Fshr, Tjp1, Aqp8, Fyn, Dhh, Ccnd2, Wt1, Gata1, Sox9, Msi1 and Inhba). The remaining 13 mRNA species showed significantly altered levels after treatment. Of these, nine showed increased expression in response to busulphan (Cst9, Shbg, Wnt5a, Clu, Il1a, Cldn11, Cys12, 4930486L24Rik (Testin) and Amh), while two showed decreased expression (Spata2 and Sympk) and two showed a mixed response ( $\operatorname{Trf}$ and $\operatorname{Inh} b b$ ). Most mRNA species showed a late response to germ cell ablation (after 15 days), although five responded within 5 days (Cst9, Shbg, Inhbb, Wnt5a and Clu) and one within 15 days (Spata2) (Fig. 5).

\section{Other testicular genes}

Levels of mRNA encoding three products with unknown ( $\beta$-defensin 36, DEFB36) or mixed somatic expression (GATA4 and NR0B1) were also measured after busulphan treatment. Levels of transcripts encoding the $\beta$-defensin DEFB36 and the transcription factor GATA4 increased significantly 30 days after treatment with busulphan and remained high up to day 50 (Fig. 6). By contrast, NrOb1 (Dax1) transcript levels were significantly reduced 50 days after treatment (Fig. 6).

\section{Discussion}

Busulphan induces apoptosis in spermatogonia within 1 week of treatment followed by a second wave of apoptosis in meiotic spermatocytes after 2 weeks (Choi et al. 2004). The expression pattern of germ cell markers was consistent with early loss of spermatogonia through apoptosis followed by loss of spermatocytes after 2 weeks and subsequent loss of spermatids between 20 and 30 days as existing spermatids mature and fail to be replaced. Histological changes in the testis after busulphan were also consistent with the changes in marker transcript levels although there tended to be a delay between loss of marker expression and loss of a particular cell population. Overall, the histological and marker data indicate that spermatogonia entered apoptosis within 5 days of treatment followed by loss of spermatocytes after day 10 and spermatids after day 15 . By day 30 most tubules contained only the Sertoli cells and by day 50 germ cell repopulation was apparent in some tubules. It should be noted that since busulphan is a cytotoxic drug there is a possibility that it will also have direct effects on the somatic cells of the testis. It might be expected that any such effects would be rapid and, within any one cell type, have a relatively non-specific effect on transcript levels. Within the confines of the experimental design, however, no effects of this nature were seen apart from some early increases in specific Sertoli cell transcript levels (discussed below).

Treatment with busulphan had no effect on intratesticular levels of testosterone confirming previous studies which have shown no effect of germ cell ablation on testosterone levels (Gomes et al. 1973, Morris et al. 1987, De Franca et al. 1994). Consistent with the failure to alter testicular androgen levels, busulphan treatment had no effect on levels of mRNA transcripts encoding proteins involved in steroidogenesis. Use of an external standard control for the real-time PCR studies meant that transcript levels were normalised to the whole testis and were, therefore, unaffected by changes in testis volume or cellular composition induced by busulphan. In addition, total Leydig cell number is unaffected by busulphan treatment in the adult mouse ( $\mathrm{O}^{\prime}$ Shaughnessy et al. 2003) and no corrections to the measured transcript 
levels per testis were required $\left(\mathrm{O}^{\prime}\right.$ Shaughnessy et al. $2007 a, 2007 b$ ). The constant transcript levels per testis after busulphan treatment indicates, therefore, that there is no change in level per Leydig cell. This failure of germ cell ablation to affect the steroidogenic function of the Leydig cells in the adult animal contrasts with the reported effect of germ cell ablation in the fetal or prepubertal rat (Boujrad et al. 1995a, 1995b). Under these circumstances, Leydig cell number is reduced in the adult animal but testosterone production per cell is increased (Boujrad et al. 1995a, 1995b). This would suggest that germ cells are required at the pre-pubertal stage for normal development of Leydig cell number and function but that the Leydig cells become independent of germ cell regulation once the adult cohort is formed. Alternatively, it has been shown that cryptorchidism appears to have different effects on Leydig cell function in rats and mice (de Kretser et al. 1979, Jegou et al. 1983, Mendis-Handagama et al. 1990a, 1990b, Murphy \& O'Shaughnessy 1991) and it is possible that there is a species difference in the Leydig cell response to germ cell depletion.

In contrast to the steroidogenic apparatus, levels of mRNA encoding PDGF-A were significantly reduced coinciding with ablation of the spermatid population. This growth factor is required for normal Leydig cell development around puberty and is predominantly expressed in the Sertoli cells in the immature testis but in the adult animal it is localised in the Leydig cells (Gnessi et al. 2000, Fecteau et al. 2006). Altered expression of Pdgfa after busulphan suggests, therefore, that germ cell ablation can affect specific Leydig cell functions and this is likely to occur through changes in Sertoli cell activity.

The failure of germ cell ablation to affect circulating FSH levels was somewhat surprising since busulphan caused transient but significant changes in inhibin $\beta B$-subunit mRNA levels and previous studies have shown that busulphan will increase circulating FSH levels in the rat between 6 and 10 weeks after injection (Gomes et al. 1973, Morris et al. 1987). The lack of a similar phenomenon in the mouse may be indicative of a species difference but a contributing factor in this study may also be that an outbred strain of mouse was used. This has the advantage that inbred strain-specific effects are avoided but at the expense of an overall increase in animal to animal variability which may have masked subtle changes in hormone levels.

Despite failure to affect androgen or FSH levels, germ cell ablation had a marked and widespread effect on the Sertoli cells. This study examined 26 mRNA species that have been shown, within the testis, to be predominantly or exclusively expressed in the Sertoli cells (Table 1). Of the genes studied over $50 \%$ showed altered expression following germ cell ablation and since hormone levels were unaffected this is likely to be a direct response to the loss of germ cells. In addition, since busulphan treatment does not affect Sertoli cell number (O'Shaughnessy et al. 2003) changes in transcript levels per testis will be a reflection of changes per Sertoli cell. While extrapolation from this set of genes should be done with caution, the results indicate that a large number of Sertoli cell genes may be directly regulated by the germ cell component. Most of the genes affected by busulphan showed a late response (after 15 days) which indicates that Sertoli cell activity is particularly sensitive to regulation by the spermatid population. This is consistent with earlier in vivo studies which showed that spermatids are primarily responsible for changes in Sertoli cell function (Jegou et al. 1993, Maguire et al. 1993, McKinnell \& Sharpe 1997). In addition, more recent in vitro studies using co-culture methods have shown specific effects of post-meiotic germ cells on Sertoli cell function (Vidal et al. 2001, Delfino et al. 2003). Sertoli cell activity also appears to be regulated by other germ cell populations and, in particular, the meiotic germ cells (Rey et al. 1994, Al Attar et al. 1997, Grandjean et al. 1997, Syed et al. 1999), although spermatogonia may also be involved (Fujino et al. 2006). This would be consistent with the earlier changes seen in mRNA species such as Shbg and Cst9 and the loss of Spata2 around day 15. As discussed above, it is also possible that early effects of busulphan could be due to direct effects of the drug on Sertoli cell activity but this appears unlikely since only a small number of genes are affected and in each case activity is increased after treatment.

Two recent studies have shown that there is high expression of $\beta$-defensins in the testis and male reproductive tract (Patil et al. 2005, Yenugu et al. 2006). In both studies, $\beta$-defensin 36 was shown to be abundantly expressed in the testis and we have included it as a representative $\beta$-defensin in this study. While $\beta$-defensins are generally expressed in epithelia the specific localisation of Defb36 expression in the testis is uncertain and Defb36 has not been considered with the other two groups. Results from this study show clearly that germ cell ablation will significantly increase Defb36 mRNA levels. The $\beta$-defensins act as broad spectrum antimicrobials which help protect the male reproductive tract against infection (Selsted \& Ouellette 2005). It might, therefore, be expected that ablation of the germ cell population would act to increase levels of $\beta$-defensins as a protective response. During development, the transcription factor GATA4 and the nuclear receptor NROB1 (DAX1) are involved in sex determination and differentiation of the fetal Leydig cells (LaVoie 2003, Park et al. 2005, Bielinska et al. 2007). In adult animals, their function is less clear although both may be involved in maintenance and regulation of steroidogenesis (LaVoie 2003, Niakan \& McCabe 2005). The two factors are expressed in the both Sertoli cells and Leydig cells in the adult animal (Tamai et al. 1996, Ketola et al. 1999) and the late changes in transcript levels after 
busulphan treatment indicates that normal expression of these factors is regulated by the germ cells. It is not clear whether this regulation occurs in both cell types or is restricted to only one.
Previous studies have examined the role of germ cells in the regulation of a small number of the mRNA species studied in this report at the mRNA level or as secreted proteins. During normal development, there is a marked,
A
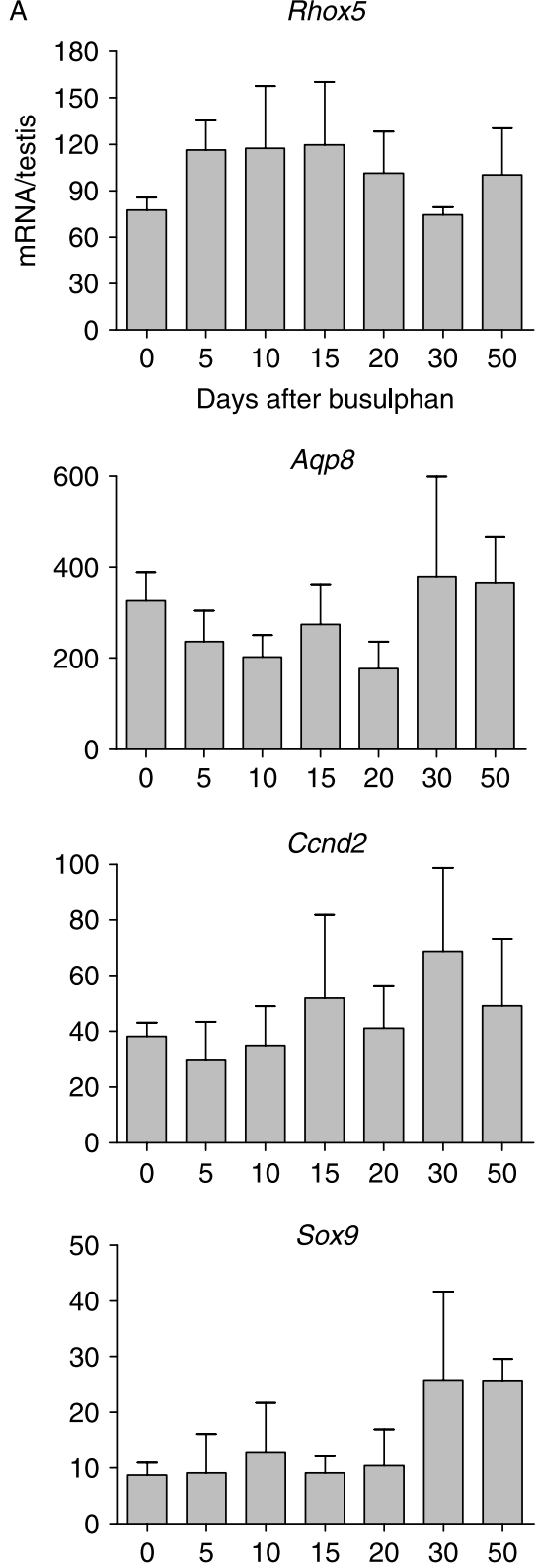

Espn

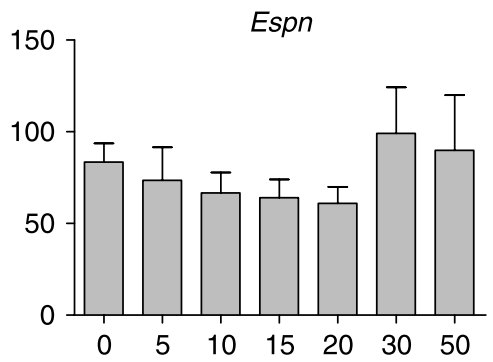

Fshr
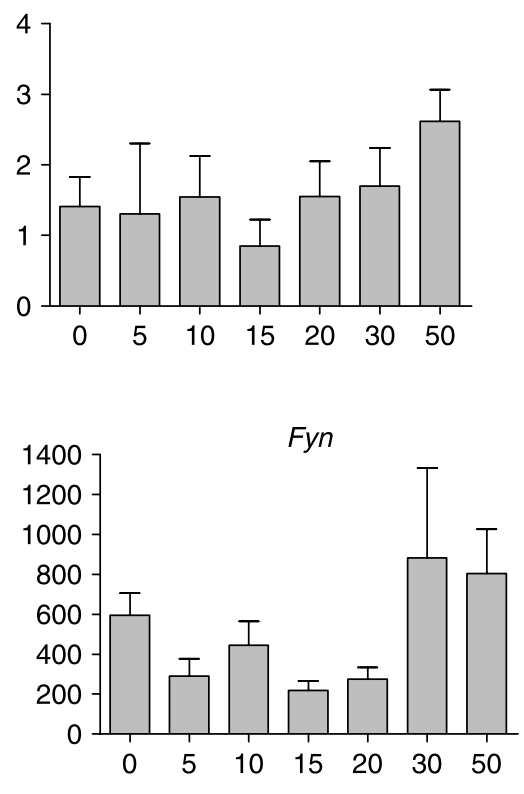

Wt1

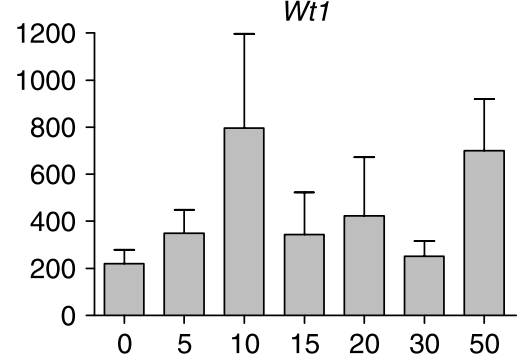

Msi1

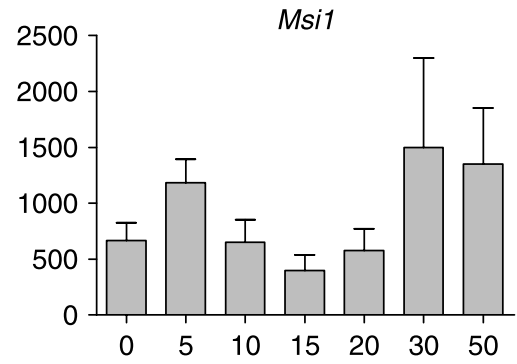

Tjp1
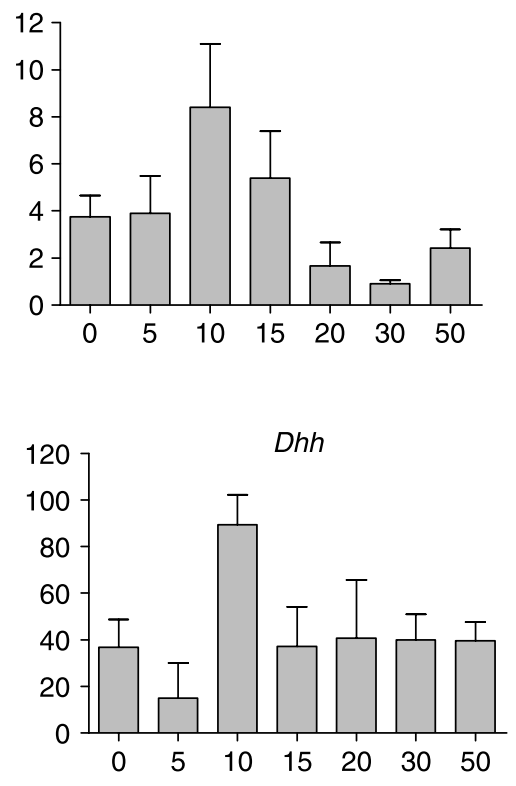

Gata1

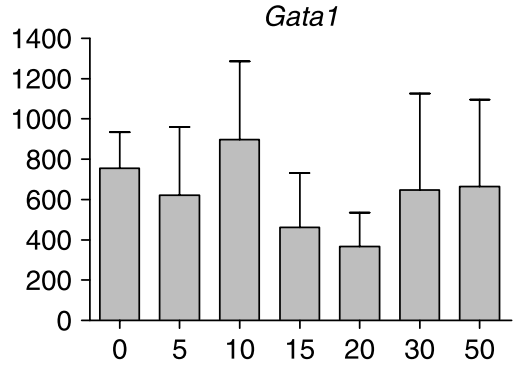

Inhba

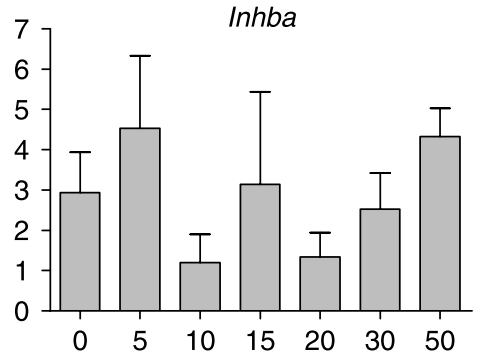

Figure 5 (legend continued) 

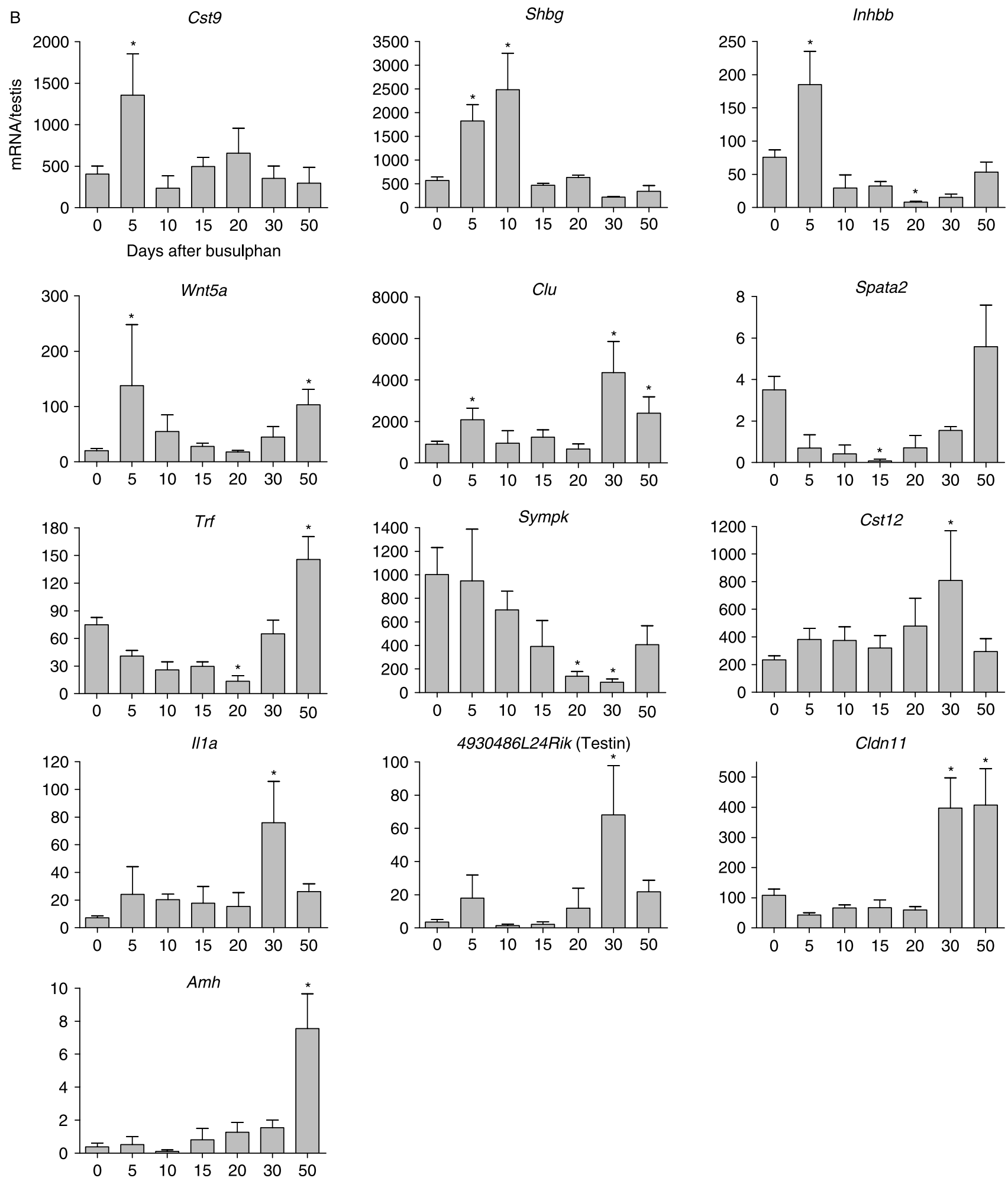

Figure 5 (A) Effect of busulphan treatment on levels of mRNA transcripts encoding markers of Sertoli cell-specific products. Expression was measured by real-time PCR, and results are expressed relative to the external control luciferase. The results are expressed as mean \pm s.E.M. for four or five animals in each busulphan-treated group and 18 animals in the control group. Transcripts showing no change in levels after busulphan treatment have been grouped in (A). (B) Effect of busulphan treatment on levels of mRNA transcripts encoding markers of Sertoli cell-specific products. Expression was measured by real-time PCR, and results are expressed relative to the external control luciferase. The results are expressed as mean \pm s.E.M. for four or five animals in each busulphan-treated group and 18 animals in the control group. Transcripts showing a significant difference to control values $(P<0.05$, marked $*)$ have been grouped (B) and are ordered according to the time at which an effect of busulphan is first seen. 

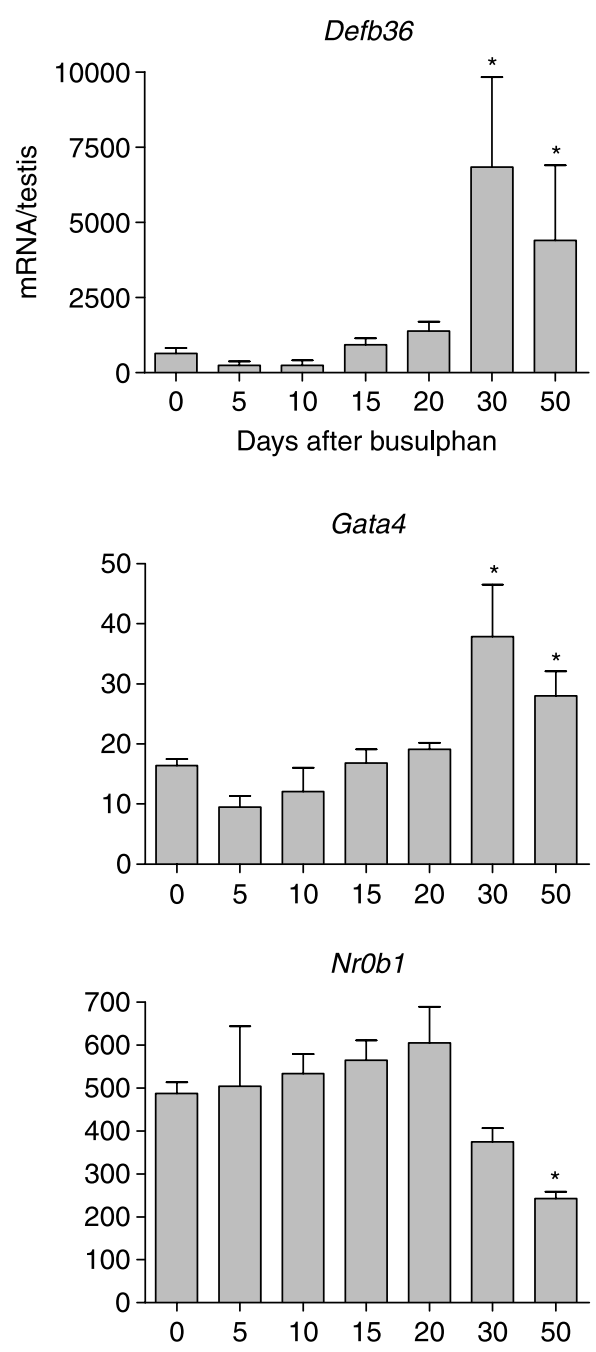

Figure 6 Effect of busulphan treatment on levels of mRNA transcripts encoding DEFB36, GATA4 and NROB1 (DAX1). Expression was measured by real-time PCR, and results are expressed relative to the external control luciferase. The results are expressed as mean \pm S.E.M. for four or five animals in each busulphan-treated group and 18 animals in the control group. Groups marked with an asterisk $\left(^{*}\right)$ are significantly $(P<0.05)$ different from control values.

prepubertal decline in anti-Müllerian hormone $(\mathrm{AMH})$ secretion by the Sertoli cells which is likely to be caused by increased androgen action on the Sertoli cells and by germ cell entry into meiosis (Al Attar et al. 1997, Rey et al. 2003). Since there was no significant change in intratesticular androgen levels in this study, the rise in Amh after busulphan treatment is consistent with regulation by the germ cells, although the effect of busulphan was only seen after loss of the spermatid population. Similarly, it has been reported that levels of the Sertoli cell secretory product testin are inversely proportional to germ cell numbers (Cheng et al. 1989, Guitton et al. 2000) which is consistent with results reported here. A number of earlier studies have shown that inhibin B levels are regulated by germ cells and data from the rat suggests that loss of post-meiotic germ cells is associated with a decline in inhibin B (Allenby et al. 1991, Guitton et al. 2000). By contrast, Clifton et al. (2002) have reported that meiotic germ cells act to inhibit Sertoli cell Inhbb mRNA levels in culture. Interestingly, it has been shown that inhibin B production appears to be germ cell stage dependent with a possible inhibitory effect of interleukin (IL) $1 \alpha$ at the nadir of production (Okuma et al. 2006). The changes in Inhbb mRNA levels seen after busulphan in this study may, therefore, be related to disruption of the normal stagedependent regulation of Sertoli cell activity, although the alteration in II1 a transcript levels after germ cell depletion may also play a role. Sertoli cell activin A production has also been shown to be germ cell stage dependent (Okuma et al. 2006) but Inhba transcript levels per testis did not change significantly after busulphan. This would suggest that there can be a complex effect of overall germ cell depletion on Sertoli cell transcripts which normally are under stage-dependent regulation. This may be because the overall effect of germ cell ablation will be a balance between the stimulatory and inhibitory effects of stage regulation aggregated across the whole testis.

Results from this study indicate, overall, that germ cells play a major (mostly inhibitory) role in regulating Sertoli cell activity and that this regulation is primarily through the post-meiotic cells. The effects of germ cell ablation were widespread, affecting $50 \%$ of the mRNA species tested suggesting that the germ cells may have a greater overall effect on Sertoli cell activity than endocrine factors which tend to be more specific (Johnston et al. 2004, Denolet etal. 2006). It is likely that the overall effect of germ cell action is to fine-tune Sertoli cell activity during the different stages of spermatogenesis in order to maximise spermatogenic output.

\section{Materials and Methods}

\section{Animals}

Adult (15 weeks) outbred MF1 mice were purchased from Harlan UK (Bicester, UK). Mice were given a single injection (i.p.) of busulphan $(30 \mathrm{mg} / \mathrm{kg})$ in $\mathrm{DMSO} / \mathrm{H}_{2} \mathrm{O}(50 / 50 \mathrm{v} / \mathrm{v})$ and were killed 5, 10, 15, 20, 30 or 50 days later. At each time point, three or four control animals and five treated animals were killed to allow for any effects of ageing of the mice. No significant differences between the control animals were seen and data from the control animals were pooled for analysis.

One testis from each animal was frozen in liquid $\mathrm{N}_{2}$ while the other testis was weighed and cut into half. One half was frozen for subsequent measurement of intratesticular testosterone, while the other half was fixed in Bouin's. Trunk blood was collected from animals and serum used to measure circulating FSH.

\section{Measurement of mRNA levels}

Real-time PCR was used to quantify the content of specific mRNA species in the testes at different times following busulphan treatment. To allow specific mRNA levels to be expressed per 
Table 1 Primer sequences used for real-time PCR.

\begin{tabular}{|c|c|c|c|c|c|}
\hline Gene & Abbrev. & GenBank & Forward primer & Reverse primer & Reference to mRNA localisation ${ }^{a}$ \\
\hline \multicolumn{6}{|l|}{ Sertoli cell } \\
\hline Anti-Mullerian hormone & Amh & nm_007445 & TCCTACATCTGGCTGAAGTGATATGGG & AGGTTCTGTGTGCCCCGCAG & $\begin{array}{l}\text { Munsterberg \& } \\
\text { Lovell-Badge (1991) }\end{array}$ \\
\hline Aquaporin 8 & Aqp8 & nm_007474 & GCTGGCAGTCACAGTGATCGGA & СCTGGACGATGGCAAAGGCTG & Badran \& Hermo (2002) \\
\hline Claudin 11 & Cldn11 & nm_008770 & GCTCCAAGGGCCTGTGGGC & TGTCAACAGCAGCAAGATGGCG & Morita et al. (1999) \\
\hline Clusterin & Clu & nm_013492 & ССАСGССАTGAАGATTСТССТGC & СТСССТGGACGGCGTTCTGA & Morales et al. (1987) \\
\hline Cyclin D2 & Ccnd2 & nm_009829 & GGAACCTGGCCGCAGTCACC & AATCATCGACGGCGGGTACATG & Tan et al. $(2005 b)$ \\
\hline Cystatin 12 & Cst12 & af440737 & GGATGACGATTTTGCCTACAAGTTCCT & ТTСТСТСТССТGGАССТTССТGСА & Li et al. (2002) \\
\hline Cystatin 9 (Testatin) & Cst9 & nm_009979 & GATATTTGCCСCTTTCAGGAGAGCC & AGAGAAGTACGTGACCAGTCCATGGG & Kanno et al. (1999) \\
\hline Desert hedgehog & Dhh & nm_007857 & GGCGCAGACCGCCTGATG & AAGGCACGGCCTTCGTAGTGG & Bitgood et al. (1996) \\
\hline Espin & Espn & nm_019585 & GCTTCTGGTCGGGCATTACCCT & GTGTCATGCCGTCTTGGGCG & Bartles et al. (1996) \\
\hline $\begin{array}{l}\text { Follicle stimulating hormone } \\
\text { receptor }\end{array}$ & Fshr & nm_013523 & GGCCAGGTCAACATACCGCTTG & TGCCTTGAAATAGACTTGTTGCAAATTG & Kliesch et al. (1992) \\
\hline Fyn proto-oncogene & Fyn & nm_008054 & GAAGCGGCCСТGTATGGAAGGTT & TGTGGGCAGGGCATCCTATAGC & Maekawa et al. (2002) \\
\hline GATA binding protein 1 & Gata1 & nm_008089 & ATGGTCAGAACCGGCCTCTCATC & GAGCTTGAAATAGAGGCCGCAGG & Tan et al. (2005a) \\
\hline Inhibin $\beta-A$ & Inhba & bc053527 & CATGGAGCAGACCTCGGAGATCA & TGGTCCTGGTTCTGTTAGCCTTGG & Kaipia et al. (1992) \\
\hline Inhibin $\beta-B$ & Inhbb & nm_008381 & GAGCGCGTCTCCGAGATCATCA & СGTACСТTССТССТGСТGСССТT & Kaipia et al. (1992) \\
\hline Interleukin $1 \alpha$ & Il1a & nm_010554 & TTGGCGCTTGAGTCGGCAAA & TCATGAAGTGAGCCATAGCTTGCATC & Jonsson et al. (1999) \\
\hline Musashi homolog 1 & Msi1 & nm_008629 & TCACTTTCATGGACCAGGCGG & GTTCACAGACAGCССССССА & Saunders et al. (2002) \\
\hline Reproductive homeobox 5 & Rhox5 & nm_008818 & AGGTTCGCCCAGCATCGACTG & GCCGCAGСССТССТGATCTT & Lindsey \& Wilkinson (1996) \\
\hline RIKEN 4930486L24 (Testin) & $\begin{array}{l}\text { 4930486L24- } \\
\text { Rik }\end{array}$ & ay146988 & AAAGACAATGGCGGCCTCGC & GGCCCCACTTTAGCCACTGCC & Cheng et al. (1989) \\
\hline Sex hormone binding globulin & Shbg & nm_011367 & GACATTCСССАGССТСАТGСА & TGCCTCGGAAGACAGAACCACG & Wang et al. (1989) \\
\hline Spermatogenesis associated 2 & Spata2 & nm_170756 & GCCGTGTGGGCCTGTGCTT & TTCCССАAATCAAACCCAAGGG & Graziotto et al. (1999) \\
\hline SRY-box containing gene 9 & Sox9 & nm_011448 & CGCGGAGCTCAGCAAGACTCTG & TGTCCGTTCTTCACCGACTTCCTC & Frojdman et al. (2000) \\
\hline Symplekin & sympk & $\mathrm{xm}_{-} 485873$ & CAAGAAGAAGGGCCAAGCATCGA & AGGAAGTTGTCAAGCAGGGTGGG & Keon et al. (1996) \\
\hline Tight junction protein 1 & Tjp1 & nm_009386 & GCGGAGAGAGACAAGATGTCCGC & СТCTGAAAATGAGGATTATCTCTTCCACCA & Byers et al. (1991) \\
\hline Transferin & Trf & nm_133977 & CAAATGCATCAGCTTCCGTGACC & CGGCATCGTACACCCAACCC & Skinner \& Griswold (1980) \\
\hline Wilms tumour homolog & Wt1 & nm_144783 & GCTCСAGCTCAGTGAAATGGACAGAA & GGCCACTCCAGATACACGCCG & Mundlos et al. (1993) \\
\hline $\begin{array}{l}\text { Wingless-related MMTV integration } \\
\text { site 5A }\end{array}$ & Wnt5a & nm_009524 & СТGCTTCTACCATGCGTTTGCTGG & GCCATGGGACAGTGCGGC & $\begin{array}{l}\text { O'Shaughnessy et al. (2007a, } \\
2007 b)\end{array}$ \\
\hline \multicolumn{6}{|l|}{ Leydig cell } \\
\hline $\begin{array}{l}\text { Cytochrome P450 side chain clea- } \\
\text { vage }\end{array}$ & Cyp11a1 & nm_019779 & CACAGACGCATCAAGCAGCAAAA & GCATTGATGAACCGCTGGGC & O'Shaughnessy et al. (2002) \\
\hline $\begin{array}{l}\text { 3B-hydroxysteroid dehydrogenase } \\
\text { type } 6\end{array}$ & Hsd3b6 & nm_013821 & GCTCCAGACTGGGACTGCTGACAC & АATCСТСТGGСССАAAAACССТС & O'Shaughnessy et al. (2002) \\
\hline StAR protein & Star & nm_011485 & CGTCGGAGCTCTCTGCTTGGTTC & TCGTCCCCGTTCTCCTGCTG & O'Shaughnessy et al. (2002) \\
\hline Cytochrome P450 17 $\alpha$-hydroxylase & Cyp17a1 & nm_007809 & TGGTCCСATCTATTCTCTTCGCCTG & AGGCGACGCCTTTTCCTTGG & O'Shaughnessy et al. (2002) \\
\hline Luteinising hormone receptor & Lhr & nm_013582 & TCAGGAATTTGCCGAAGAAAGAACAG & GAAGTCATAATCGTAATCCCAGCCACTG & O'Shaughnessy et al. (2002) \\
\hline Platelet -derived growth factor $\mathrm{A}$ & Pdgfa & nm_008808 & GAGCGGCTGGCTCGAAGTCAG & CTGCGAATGGGCACAGGCC & Gnessi et al. (1995) \\
\hline \multicolumn{6}{|l|}{ Germ cell } \\
\hline Transition protein 1 & Tnp1 & nm_009407 & GGCGATGATGCAAGTCGCAA & ССАCTCTGATAGGATCTTTGGCTTTTGG & Yelick et al. (1989) \\
\hline Sporulation protein meiosis-specific & Spo11 & nm_012046 & CGCGTGGCCTCTAGTTCTGAGG & GGTATCATCCGAAGGCCGACAGAAT & Shannon et al. (1999) \\
\hline Stimulated by retinoic acid gene 8 & Stra8 & nm_009292 & GAAGGTGCATGGTTCACCGTGG & GCTCGATGGCGGGCCTGTG & Oulad-Abdelghani et al. (1996) \\
\hline \multicolumn{6}{|l|}{ Others } \\
\hline$\beta$-defensin 36 & Defb36 & $\begin{array}{l}\mathrm{n}- \\
\mathrm{m} \_0010372- \\
47\end{array}$ & TCCCCAGTACGCCACGAACG & TTGCCGTGGAGATTCCAGCATT & see text \\
\hline Gata binding protein 4 & Gata4 & nm_008092 & СССТTCGACAGСССАGTCСТG & AGGTAGTGTCCСGTCCСАTCTCG & Ketola et al. (1999) \\
\hline $\begin{array}{l}\text { Nuclear receptor subfamily 0b1 } \\
\text { (Dax1) }\end{array}$ & Nrob1 & nm_007430 & CGGAGGCTGGGCACTTGCT & CAATGTATTTCACGCACTGCAGGC & Tamai et al. (1996) \\
\hline
\end{tabular}

${ }^{\text {a }}$ Reference describing localisation of mRNA transcripts in the testis. 
testis and to control for the efficiency of RNA extraction, RNA degradation and the RT step, an external standard (luciferase; Promega UK) was used (Baker \& O'Shaughnessy 2001, O'Shaughnessy et al. 2002, Johnston et al. 2004). Testis RNA was extracted using Trizol (Life Technologies) and luciferase mRNA (5 ng) was added to each testis at the start of the RNA extraction procedure. Residual genomic DNA was removed from extracted RNA by DNAse treatment (DNA-free; Ambion Inc., supplied by AMS Biotechnology, Abingdon, UK). The RNA was reverse transcribed using random hexamers and Moloney murine leukaemia virus reverse transcriptase (Superscript II, Life Technologies) as described previously (O'Shaughnessy \& Murphy 1993, O'Shaughnessy et al. 1994).

Measurement by real-time PCR used the SYBR method in a 96-well plate format. Reactions contained $5 \mu \mathrm{l} 2 \times$ SYBR mastermix (Stratagene, Amsterdam, The Netherlands), primer $(100 \mathrm{nM})$ and template in a total volume of $10 \mu \mathrm{l}$. The thermal profile used for amplification was $95^{\circ} \mathrm{C}$ for $8 \mathrm{~min}$ followed by 40 cycles of $95{ }^{\circ} \mathrm{C}$ for $20 \mathrm{~s}, 63^{\circ} \mathrm{C}$ for $20 \mathrm{~s}$ and $72{ }^{\circ} \mathrm{C}$ for $30 \mathrm{~s}$. At the end of the amplification phase, a melting curve analysis was carried out on the products formed and gel electrophoresis was carried out on representative samples to confirm product size. The quantity of each measured cDNA was expressed relative to the internal standard in the same sample, which allows direct comparison of expression levels per testis between different samples (Johnston et al. 2004).

Primers were designed using PrimerExpress software (Applied Biosystems, Warrington, UK) using parameters described previously (O'Shaughnessy et al. 2007a, 2007b). The primers used are shown in Table 1.

\section{Measurement of hormone levels}

Levels of FSH in the serum were measured using a commercial RIA with rat standards (Amersham Biosciences). A dilution curve of mouse serum was parallel with the standard curve generated by the RIA. To measure intratesticular testosterone levels, steroids were extracted from frozen hemi-testes in ethanol and measured by RIA as previously described (O'Shaughnessy \& Sheffield 1990).

\section{Histology}

Testes were fixed overnight in Bouin's and stored in $70 \%$ ethanol. Testes were embedded in Technovit 7100 resin, cut into sections and stained with Harris' hematoxylin and eosin.

\section{Statistical analysis}

Effects of drug treatment were analysed initially by single-factor ANOVA followed by post hoc analysis using Fisher's test.

\section{Acknowledgements}

These studies were supported by a grant from the Wellcome Trust. We should like to thank Ana Monteiro for technical assistance. The authors declare that there is no conflict of interest that would prejudice the impartiality of this scientific work.

\section{References}

Al Attar L, Noel K, Dutertre M, Belville C, Forest MG, Burgoyne PS, Josso N \& Rey R 1997 Hormonal and cellular regulation of Sertoli cell antiMullerian hormone production in the postnatal mouse. Journal of Clinical Investigation 100 1335-1343.

Allenby G, Foster PM \& Sharpe RM 1991 Evidence that secretion of immunoactive inhibin by seminiferous tubules from the adult rat testis is regulated by specific germ cell types: correlation between in vivo and in vitro studies. Endocrinology 128 467-476.

Badran HH \& Hermo LS 2002 Expression and regulation of aquaporins 1, 8, and 9 in the testis, efferent ducts, and epididymis of adult rats and during postnatal development. Journal of Andrology 23 358-373.

Baker PJ \& O'Shaughnessy PJ 2001 Expression of prostaglandin D synthetase during development in the mouse testis. Reproduction 122 553-559.

Bartles JR, Wierda A \& Zheng L 1996 Identification and characterization of espin, an actin-binding protein localized to the F-actin-rich junctional plaques of Sertoli cell ectoplasmic specializations. Journal of Cell Science 109 1229-1239.

Bergh A \& Soder O 2007 Studies of cryptorchidism in experimental animal models. Acta Paediatrica 96 617-621.

Bielinska M, Seehra A, Toppari J, Heikinheimo M \& Wilson DB 2007 GATA-4 is required for sex steroidogenic cell development in the fetal mouse. Developmental Dynamics 236 203-213.

Bitgood MJ, Shen L \& McMahon AP 1996 Sertoli cell signaling by Desert hedgehog regulates the male germline. Current Biology 6 298-304.

Boitani C, Ritzén EM \& Parvinen M 1981 Inhibition of rat Sertoli cell aromatase by factor(s) secreted specifically at spermatogenic stages VII and VIII. Molecular and Cellular Endocrinology 23 11-22.

Boujrad N, Hochereau-de Reviers MT, Kamtchouing P, Perreau C \& Carreau S 1995a Evolution of somatic and germ cell populations after busulfan treatment in utero or neonatal cryptorchidism in the rat. Andrologia 27 223-228.

Boujrad N, Hochereau-de Reviers MT \& Carreau S 1995b Evidence for germ cell control of Sertoli cell function in three models of germ cell depletion in adult rat. Biology of Reproduction 53 1345-1352.

Byers S, Graham R, Dai HN \& Hoxter B 1991 Development of Sertoli cell junctional specializations and the distribution of the tight-junctionassociated protein ZO-1 in the mouse testis. American Journal of Anatomy 191 35-47.

Cheng CY, Grima J, Stahler MS, Lockshin RA \& Bardin CW 1989 Testins are structurally related Sertoli cell proteins whose secretion is tightly coupled to the presence of germ cells. Journal of Biological Chemistry 264 21386-21393.

Choi YJ, Ok DW, Kwon DN, Chung JI, Kim HC, Yeo SM, Kim T, Seo HG \& Kim JH 2004 Murine male germ cell apoptosis induced by busulfan treatment correlates with loss of c-kit-expression in a Fas/FasL- and p53independent manner. FEBS Letters 575 41-51.

Clifton RJ, O'Donnell L \& Robertson DM 2002 Pachytene spermatocytes in co-culture inhibit rat Sertoli cell synthesis of inhibin beta B-subunit and inhibin B but not the inhibin alpha-subunit. Journal of Endocrinology 172 565-574.

Delfino FJ, Boustead JN, Fix C \& Walker WH 2003 NF-kappaB and TNF- $\alpha$ stimulate androgen receptor expression in Sertoli cells. Molecular and Cellular Endocrinology 201 1-12.

Denolet E, De Gendt K, Allemeersch J, Engelen K, Marchal K, Van Hummelen P, Tan KA, Sharpe RM, Saunders PT, Swinnen JV \& Verhoeven G 2006 The effect of a Sertoli cell-selective knockout of the androgen receptor on testicular gene expression in prepubertal mice. Molecular Endocrinology 20 321-334.

Fecteau KA, Mrkonjich L, Mason JI \& Mendis-Handagama SM 2006 Detection of platelet-derived growth factor-alpha (PDGF-A) protein in cells of Leydig lineage in the postnatal rat testis. Histology and Histopathology 21 1295-1302.

De Franca LR, Bartke A, Borg KE, Cecim M, Fadden CT, Yagi A \& Russell LD 1994 Sertoli cells in testes containing or lacking germ cells: a comparative study of paracrine effects using the W (c-kit) gene mutant mouse model. Anatomical Record 240 225-232.

Frojdman K, Harley VR \& Pelliniemi LJ 2000 Sox 9 protein in rat sertoli cells is age and stage dependent. Histochemistry and Cell Biology 113 31-36. 
Fujino RS, Tanaka K, Morimatsu M, Tamura K, Kogo H \& Hara T 2006 Spermatogonial cell-mediated activation of an IkappaBzeta-independent nuclear factor-kappaB pathway in Sertoli cells induces transcription of the lipocalin-2 gene. Molecular Endocrinology 20 904-915.

De Gendt K, Swinnen JV, Saunders PT, Schoonjans L, Dewerchin M, Devos A, Tan K, Atanassova N, Claessens F, Lecureuil C et al. 2004 A Sertoli cell-selective knockout of the androgen receptor causes spermatogenic arrest in meiosis. PNAS 101 1327-1332.

Gnessi L, Emidi A, Jannini EA, Carosa E, Maroder M, Arizzi M, Ulisse S \& Spera G 1995 Testicular development involves the spatiotemporal control of PDGFs and PDGF receptors gene expression and action. Journal of Cell Biology 131 1105-1121.

Gnessi L, Basciani S, Mariani S, Arizzi M, Spera G, Wang C, Bondjers C, Karlsson L \& Betsholtz C 2000 Leydig cell loss and spermatogenic arrest in platelet-derived growth factor (PDGF)-A-deficient mice. Journal of Cell Biology 149 1019-1026.

Gomes WR, Hall RW, Jain SK \& Boots LR 1973 Serum gonadotropin and testosterone levels during loss and recovery of spermatogenesis in rats. Endocrinology 93 800-809.

Grandjean V, Sage J, Ranc F, Cuzin F \& Rassoulzadegan M 1997 Stagespecific signals in germ line differentiation: control of Sertoli cell phagocytic activity by spermatogenic cells. Developmental Biology 184 165-174.

Graziotto R, Foresta C, Scannapieco P, Zeilante P, Russo A, Negro A, Salmaso R \& Onisto M 1999 cDNA cloning and characterization of PD1: a novel human testicular protein with different expressions in various testiculopathies. Experimental Cell Research 248 620-626.

Guitton N, Touzalin AM, Sharpe RM, Cheng CY, Pinon-Lataillade G, Meritte H, Chenal C \& Jegou B 2000 Regulatory influence of germ cells on sertoli cell function in the pre-pubertal rat after acute irradiation of the testis. International Journal of Andrology 23 332-339.

Jegou B, Laws AO \& de Kretser DM 1983 The effect of cryptorchidism and subsequent orchidopexy on testicular function in adult rats. Journal of Reproduction and Fertility 69 137-145.

Jegou B, Pineau C, Velez de la Calle JF, Touzalin AM, Bardin CW \& Cheng CY 1993 Germ cell control of testin production is inverse to that of other Sertoli cell products. Endocrinology 132 2557-2562.

Johnston H, Baker PJ, Abel M, Charlton HM, Jackson G, Fleming L, Kumar TR \& O'Shaughnessy PJ 2004 Regulation of Sertoli cell number and activity by follicle-stimulating hormone and androgen during postnatal development in the mouse. Endocrinology 145 318-329.

Jonsson CK, Zetterstrom RH, Holst M, Parvinen M \& Soder O 1999 Constitutive expression of interleukin-1 alpha messenger ribonucleic acid in rat Sertoli cells is dependent upon interaction with germ cells. Endocrinology 140 3755-3761.

Kaipia A, Penttila TL, Shimasaki S, Ling N, Parvinen M \& Toppari J 1992 Expression of inhibin beta $A$ and beta $B$, follistatin and activin-A receptor messenger ribonucleic acids in the rat seminiferous epithelium. Endocrinology 131 2703-2710.

Kanno Y, Tamura M, Chuma S, Sakura T, Machida T \& Nakatsuji N 1999 A cystatin-related gene, testatin/cresp, shows male-specific expression in germ and somatic cells from the initial stage of murine gonadal sexdifferentiation. International Journal of Developmental Biology 43 777-784.

Keon BH, Schafer S, Kuhn C, Grund C \& Franke WW 1996 Symplekin, a novel type of tight junction plaque protein. Journal of Cell Biology 134 1003-1018.

Ketola I, Rahman N, Toppari J, Bielinska M, Porter-Tinge SB, Tapanainen JS, Huhtaniemi IT, Wilson DB \& Heikinheimo M 1999 Expression and regulation of transcription factors GATA-4 and GATA- 6 in developing mouse testis. Endocrinology 140 1470-1480.

Kliesch S, Penttila TL, Gromoll J, Saunders PTK, Nieschlag E \& Parvinen M $1992 \mathrm{FSH}$ receptor messenger-RNA is expressed stage-dependently during rat spermatogenesis. Molecular and Cellular Endocrinology 84 R45-R49.

De Kretser DM, Sharpe RM \& Swanston IA 1979 Alterations in steroidogenesis and human chorionic gonadotrophin binding in the cryptorchid rat testis. Endocrinology 105 135-138.

Kumar TR, Wang Y, Lu N \& Matzuk MM 1997 Follicle stimulating hormone is required for ovarian follicle maturation but not male fertility. Nature Genetics 15 201-204.

LaVoie HA 2003 The role of GATA in mammalian reproduction. Experimental Biology and Medicine 228 1282-1290.
Li Y, Friel PJ, Robinson MO, McLean DJ \& Griswold MD 2002 Identification and characterization of testis- and epididymis-specific genes: cystatin SC and cystatin TE-1. Biology of Reproduction 67 1872-1880.

Lindsey JS \& Wilkinson MF 1996 Pem: a testosterone-regulated and LH-regulated homeobox gene expressed in mouse sertoli cells and epididymis. Developmental Biology 179 471-484.

Lyon MF \& Hawkes SG 1970 X-linked gene for testicular feminization in the mouse. Nature 227 1217-1219.

Maekawa M, Toyama Y, Yasuda M, Yagi T \& Yuasa S 2002 Fyn tyrosine kinase in Sertoli cells is involved in mouse spermatogenesis. Biology of Reproduction 66 211-221.

Le Magueresse B \& Jégou B 1986 Possible involvement of germ cells in the regulation of oestradiol-17 beta and $\mathrm{ABP}$ secretion by immature rat Sertoli cells (in vitro studies). Biochemical and Biophysical Research Communications 141 861-869.

Maguire SM, Millar MR, Sharpe RM \& Saunders PT 1993 Stage-dependent expression of mRNA for cyclic protein 2 during spermatogenesis is modulated by elongate spermatids. Molecular and Cellular Endocrinology 94 79-88.

McKinnell C \& Sharpe RM 1997 Regulation of the secretion and synthesis of rat Sertoli cell SGP-1, SGP-2 and CP-2 by elongate spermatids. International Journal of Andrology 20 171-179.

Mendis-Handagama SM, Kerr JB \& de Kretser DM 1990a Experimental cryptorchidism in the adult mouse: I. Qualitative and quantitative light microscopic morphology. Journal of Andrology 11 539-547.

Mendis-Handagama SM, Kerr JB \& de Kretser DM 1990b Experimental cryptorchidism in the adult mouse: II. A hormonal study. Journal of Andrology 11 548-554.

Morales C, Hugly S \& Griswold MD 1987 Stage-dependent levels of specific mRNA transcripts in Sertoli cells. Biology of Reproduction $\mathbf{3 6}$ 1035-1046.

Morita K, Sasaki H, Fujimoto K, Furuse M \& Tsukita S 1999 Claudin$11 /$ OSP-based tight junctions of myelin sheaths in brain and Sertoli cells in testis. Journal of Cell Biology 145 579-588.

Morris ID, Bardin CW, Musto NA, Thau RB \& Gunsalus GL 1987 Evidence suggesting that germ cells influence the bidirectional secretion of androgen binding protein by the seminiferous epithelium demonstrated by selective impairment of spermatogenesis with busulphan. International Journal of Andrology 10 691-700.

Mruk DD \& Cheng CY 2004 Sertoli-Sertoli and Sertoli-germ cell interactions and their significance in germ cell movement in the seminiferous epithelium during spermatogenesis. Endocrine Reviews 25 747-806.

Mundlos S, Pelletier J, Darveau A, Bachmann M, Winterpacht A \& Zabel B 1993 Nuclear localization of the protein encoded by the Wilms' tumor gene WT1 in embryonic and adult tissues. Development 119 1329-1341.

Munsterberg A \& Lovell-Badge R 1991 Expression of the mouse antiMullerian hormone gene suggests a role in both male and female sexual differentiation. Development 113 613-624.

Murphy L \& O'Shaughnessy PJ 1991 Effect of cryptorchidism on testicular and Leydig cell androgen production in the mouse. International Journal of Andrology 14 66-74.

Niakan KK \& McCabe ER 2005 DAX1 origin, function, and novel role. Molecular Genetics and Metabolism 86 70-83.

Okuma Y, O'Connor AE, Hayashi T, Loveland KL, de Kretser DM \& Hedger MP 2006 Regulated production of activin A and inhibin B throughout the cycleof the seminiferous epithelium in the rat. Journal of Endocrinology $190331-340$.

O'Shaughnessy PJ \& Murphy L 1993 Cytochrome P-450 17 $\alpha$-hydroxylase protein and mRNA in the testis of the testicular feminized ( $\mathrm{Tfm}$ ) mouse. Journal of Molecular Endocrinology 11 77-82.

O'Shaughnessy PJ \& Sheffield JW 1990 Effect of testosterone on testicular steroidogenesis in the hypogonadal (hpg) mouse. Journal of Steroid Biochemistry 35 729-734.

O'Shaughnessy PJ, Marsh P \& Dudley K 1994 Follicle-stimulating hormone receptor $m R N A$ in the mouse ovary during post-natal development in the normal mouse and in the adult hypogonadal (hpg) mouse: structure of alternate transcripts. Molecular and Cellular Endocrinology 101 197-201.

O'Shaughnessy PJ, Willerton L \& Baker PJ 2002 Changes in Leydig cell gene expression during development in the mouse. Biology of Reproduction 66 966-975. 
O'Shaughnessy PJ, Fleming L, Baker PJ, Jackson G \& Johnston H 2003 Identification of developmentally regulated genes in the somatic cells of the mouse testis using serial analysis of gene expression. Biology of Reproduction 69 797-808.

O'Shaughnessy PJ, Abel M, Charlton HM, Hu B, Johnston H \& Baker PJ 2007 a Altered expression of genes involved in regulation of vitamin a metabolism, solute transportation, and cytoskeletal function in the androgen-insensitive tfm mouse testis. Endocrinology 148 2914-2924.

O'Shaughnessy PJ, Baker PJ, Monteiro A, Cassie S, Bhattacharya S \& Fowler PA 2007b Developmental changes in human fetal testicular cell numbers and messenger ribonucleic acid levels during the second trimester. Journal of Clinical Endocrinology and Metabolism 92 4792-4801.

Oulad-Abdelghani M, Bouillet P, Decimo D, Gansmuller A, Heyberger S, Dolle P, Bronner S, Lutz Y \& Chambon P 1996 Characterization of a premeiotic germ cell-specific cytoplasmic protein encoded by Stra8, a novel retinoic acid-responsive gene. Journal of Cell Biology 135 469-477.

Park SY, Meeks JJ, Raverot G, Pfaff LE, Weiss J, Hammer GD \& Jameson JL 2005 Nuclear receptors Sf1 and Dax1 function cooperatively to mediate somatic cell differentiation during testis development. Development 132 2415-2423.

Patil AA, Cai Y, Sang Y, Blecha F \& Zhang G 2005 Cross-species analysis of the mammalian beta-defensin gene family: presence of syntenic gene clusters and preferential expression in the male reproductive tract. Physiological Genomics 23 5-17.

Rey R, Mebarki F, Forest MG, Mowszowicz I, Cate RL, Morel Y, Chaussain JL \& Josso N 1994 Anti-Mullerian hormone in children with androgen insensitivity. Journal of Clinical Endocrinology and Metabolism 79 960-964.

Rey R, Lukas-Croisier C, Lasala C \& Bedecarras P 2003 AMH/MIS: what we know already about the gene, the protein and its regulation. Molecular and Cellular Endocrinology 211 21-31.

Russell LD, Warren J, Debeljuk L, Richardson LL, Mahar PL, Waymire KG, Amy SP, Ross AJ \& MacGregor GR 2001 Spermatogenesis in Bclwdeficient mice. Biology of Reproduction 65 318-332.

Saunders PT, Maguire SM, MacPherson S, Fenelon MC, Sakakibara S \& Okano H 2002 RNA binding protein Musashi1 is expressed in sertoli cells in the rat testis from fetal life to adulthood. Biology of Reproduction 66 500-507.

Selsted ME \& Ouellette AJ 2005 Mammalian defensins in the antimicrobial immune response. Nature Immunology 6 551-557.

Shannon M, Richardson L, Christian A, Handel MA \& Thelen MP 1999 Differential gene expression of mammalian SPO11/TOP6A homologs during meiosis. FEBS Letters 462 329-334.
Skinner MK \& Griswold MD 1980 Sertoli cells synthesize and secrete transferrin-like protein. Journal of Biological Chemistry 255 9523-9525.

Syed V, Gomez E \& Hecht NB 1999 Messenger ribonucleic acids encoding a serotonin receptor and a novel gene are induced in Sertoli cells by a secreted factor(s) from male rat meiotic germ cells. Endocrinology 140 5754-5760.

Tamai KT, Monaco L, Alastalo TP, Lalli E, Parvinen M \& Sassone-Corsi P 1996 Hormonal and developmental regulation of DAX-1 expression in Sertoli cells. Molecular Endocrinology 10 1561-1569.

Tan KA, De Gendt K, Atanassova N, Walker M, Sharpe RM, Saunders PT, Denolet E \& Verhoeven G 2005a The role of androgens in Sertoli cell proliferation and functional maturation: studies in mice with total (ARKO) or Sertoli cell-selective (SCARKO) ablation of the androgen receptor. Endocrinology 146 2674-2683.

Tan KA, Turner KJ, Saunders PT, Verhoeven G, De Gendt K, Atanassova N \& Sharpe RM 2005b Androgen regulation of stage-dependent cyclin D2 expression in Sertoli cells suggests a role in modulating androgen action on spermatogenesis. Biology of Reproduction 72 1151-1160.

Vidal F, Lopez P, Lopez-Fernandez LA, Ranc F, Scimeca JC, Cuzin F \& Rassoulzadegan M 2001 Gene trap analysis of germ cell signaling to Sertoli cells: NGF-TrkA mediated induction of Fra1 and Fos by postmeiotic germ cells. Journal of Cell Science 114 435-443.

Wang Y-M, Sullivan PM, Petrusz P, Yarbrough W \& Joseph DR 1989 The androgen-binding protein gene is expressed in CD1 mouse testis. Molecular and Cellular Endocrinology 63 85-92.

Yelick PC, Kwon YH, Flynn JF, Borzorgzadeh A, Kleene KC \& Hecht NB 1989 Mouse transition protein 1 is translationally regulated during the postmeiotic stages of spermatogenesis. Molecular Reproduction and Development 1 193-200.

Yenugu S, Chintalgattu V, Wingard CJ, Radhakrishnan Y, French FS \& Hall SH 2006 Identification, cloning and functional characterization of novel beta-defensins in the rat (Rattus norvegicus). Reproductive Biology and Endocrinology 47.

Zabludoff SD, Charron M, DeCerbo JN, Simukova N \& Wright WW 2001 Male germ cells regulate transcription of the cathepsin I gene by rat Sertoli cells. Endocrinology 142 2318-2327.

Received 8 January 2008

First decision 26 February 2008

Accepted 2 April 2008 